\title{
Соціальні настрої населення Дніпропетровська в період нацистської окупації міста (1941-1943 рр.)
}

\section{Шахрайчук I. A. Дніпровський національний університет імені Олеся Гончара}

Досліджено основні аспекти впливу окупаційної влади на соціальні настрої різних верств населення та моделювання політики «виживання» у екстримальних умовах воєнного лихоліття.

Ключові слова: мобілізація; окупація; практика сегрецагії; нацисьтський режим; терор; «трудові табори»; соціальні групи

Исследованы основные аспекты влияния оккупационной власти на социальные настроения различных слоёв населения и моделирование политики «выживания» в экстремальных условиях военного лихолетья.

Ключевые слова: мобилизация; оккупация; практика сегрегации; нацистский режим; террор; «трудовые лагеря»; социальные группы

The article is an attempt to characterize the system of management, which existed in Ukraine» and during the whole period of Nazi occupation in 1941-1943. On the basis of a large amount of documentary materials from central and oblast archive institutions of Ukraine, a study has been made relating the process of forming, as personnel management system, to the activities in the region carried out by the German military and administrative, as well as military and economic bodies and also Ukrainian auxiliary ones. The analysis of the process of forming the bodies of occupation administration and their structure was done. Outlined the organizational structure of the German authorities, who were subordinate to both military administration. Found subordination, an auxiliary competence of local administration of the occupied territories in the military zone. Identified specific causes and manifestations of destructive ad management and administrative practice of the military administration.

Great attention was paid to the role of auxiliary bodies which were formed on the basis of local inhabitants. Based on comprehensive analysis of original archival documents and scientific publications in the article to study the complex nature and features of the German authorities, who were subordinate to both military administration. Article devoted to defining the level of scientific elaboration history of Nazi Occupation regime in the Dnipropetrovsk region in modern Ukrainian historiography. The analysis of the problems of existing approaches the study of the formation of the Nazi occupation in modern Ukrainian historiography.

The work devoted of the process of forming the bodies of occupation administration and their structure was done. Great attention was paid to the role of auxiliary bodies which were formed on the basis of local inhabitants. The policy in the sphere of agriculture and industry was analyzed too. It was shown that the initial plans and try to restore Ukrainian enterprises, reform system. The activity of local intelligentsia in the sphere of revival of the cultural life in the region mentioned above was narrated. It was depicted that the military administration supported those efforts to certain degree.

Keywords: occupation; Nazi regime; terror; segregation; social group; mobilization 
Напередодні Другої світової війни відповідно до загальносоюзного перепису 1939 р. у Дніпропетровській області проживало 2 273,5 тис.осіб [25, с. 39]. 3 них близько 501 тис. (або 22\% від загальної кількості населення) у обласному центрі - Дніпропетровську. Хоча за кількістю населення місто поступалося Києву, Харкову, Одесі, воно було одним із найбільших міських центрів УРСР. Агресія нацистської Німеччини та Радянського Союзу проти Польщі у вересні 1939 р. стали початком не тільки наймасштабнішого військового конфлікту в світовій історії, а й небачених раніше міграційних процесів, які були зумовлені як об'єктивними причинами (втеча цивільного населення із зони воєнних дій), так і жорстокістю гітлерівського та сталінського тоталітарних режимів, які вдавалися до людиноненависницької практики депортацій окремих соціальних та національних груп. Достатньо цікавий факт, що відповідно до радянських документів напередодні німецько-радянської війни у 1941 р. населення Дніпропетровська становило 560 тис. осіб. Тобто протягом двох років кількість мешканців обласного центру зросла на 10,5\%.

Напередодні Другої світової війни Дніпропетровськ відзначався високою динамікою зростання. Про це свідчить рівень розвитку його інфраструктури. Так, у 1941 р. у місті діяли 12 вищих учбових закладів, 282 лікувальні установи, 92 загальноосвітні школи, 102 дитячих садочки, 4 театри, художній музей, один із найбільших історичних музеїв та інші культурні установи [34, с. 33]. Початок німецько-радянської війни 22 червня 1941 р. був сприйнятий населенням по-різному. Палітра відчуттів мешканців коливалась від здивування до неприхованого та водночас неоднозначного оптимізму. Очевидець подій лікар Микола Мошков таким чином описав найдовший день літа у щоденнику: «Що це? 3 відчаю?... В основі нібито боротьба з більшовизмом? Чому раптом через два роки війни надумав боротися з комунізмом? Усі насторожі ... Є диваки (дурні?), які ніби навіть схвалюють цей виступ?!» [15, с. 74].

Натомість офіційна преса транслювала версію про одноголосну підтримку радянської влади з боку мешканців міста. Так, газета «Зоря» повідомляла, що робітники та службовці станції Ніжньодніпровськ-Вузол під час мітингу 3 липня (одразу після виступу Й. Сталіна) заявили: «... ми ... оголошуємо себе мобілізованими в ряди народного ополчення... Ми клянемось Державному Комітету Оборони, що ми прикладемо всі сили для того, щоб наш транспорт працював чудово і забезпечив Червоній Армії повну перемогу над ворогом». Та водночас «Поведемо рішучу боротьбу з усілякими дезорганізаторами, поширювачами чуток, панікерами...» [37, с. 442]. 
Справі боротьбі із панікерством та можливими диверсійними групами противника мали слугувати винищувальні батальйони, формування яких розпочалось наприкінці червня місяця. В постанові бюро Дніпропетровського обкому КП(б)У про боротьбу з парашутними десантами і диверсантами противника в прифронтовій смузі (25. 06. 1941 р.) говорилося: «При міських районних відділах і відділеннях НКВС Дніпропетровської області створити винищувальні батальйони із 100 - 200 чоловік із числа перевіреного партійного комсомольського і радянського активу, здатного володіти зброєю. Запропонувати начальнику обласного управління НКВС негайно визначити і призначити начальниками винищувальних батальйонів надійних операційних працівників НКВС і міліції» [14, с. 37-38].

У обласному центрі боротьба зі «шпигунами» інспірована центральною та республіканською пресою, органами влади на місцях, набула форми справжньої манії, що виявлялось у курйозних, а почасти й драматичних епізодах. Згадуваний М. Мошков пише: «РАТАУ [Радіотелеграфне агентство України - I. А.] зробив необережне повідомлення до хлопчаків із пропозицією ловити диверсантів і на цьому грунті відбувається маса непорозумінь: ціла шпіономанія. Учора, наприклад, побили артиста Малого тетатру, прийнявши і його... за шпигуна» [15, с. 75]. Одночасно з початком війни із нацистською Німеччиною радянський режим проводив мобілізацію населення у лави Червоної армії. Спочатку мобілізації підлягали особи від 23 до 36 років (тобто 1905-1918 років народження), а 10 серпня вікові межі мобілізації були розширені і тепер до війська забирали чоловіків від 18 до 50 років (тобто 1890-1923 років народження) [32, с. 243].

Серед істориків триває дискусія, наскільки успішними були мобілізаційні кампанії 1941 р. Припускаємо, що їхня ефективність залежала від низки факторів: віку, соціальної приналежності особи, іiі попереднього досвіду та ін. Ймовірно, що найбільш дисципліновано підтримку Червоній Армії надава комуністично-партійний актив міста. Так, станом на 3-4 липня 1941 р. зафіксовано заяви від 7613 осіб (у тому числі 3526 жінок), які добровільно звернулися до військоматів міста 3 проханням зарахувати їх до лав армії. Паралельно органи влади здійснювали евакуацію матеріальних цінностей із території області та міста. Офіційно евакуація міста розпочалася 5 серпня. Керівник обкому партії у своїх спогадах пафосно звітував про 99 тис. вагонів із вантажами, які були відправлені з регіону на схід - до Сибіру та Уралу [5, с. 118]. Водночас про загальну 204 
евакуацію мешканців міста К. Грушевий згадує лише у період боїв за правобережну частину Дніпропетровська - 20-25 серпня.

1 серпня 1941 р. розпочинається будівництво оборонних споруджень на підступах до міста. За спогадами К. Грушевого, загалом до оборонних робіт було залучено близько 100 тис. осіб. Про ставлення до цих людей можемо судити із директив С. Будьоного (тоді - Головнокомандувач військ південно-західного напрямку) Військовій Раді Південного фронту місяцем пізніше, коли підрозділи Червоної армії напрямку намагатимуться створити лінію оборони на лівому березі Дніпра: «Треба залучити як чоловіків, які залишились у колгоспах та містах, а також жінок. Ваші мотиви, що жінки мають дітей і тому не можуть бути залучені до цих робіт безгрунтовні» [35, с. 316-317]. Підрозділи Вермахту досягли території Дніпропетровської області у середині серпня 1941 р. 19 серпня розпочався артилерійський обстріл Дніпропетровська, 22 серпня ворог захопив промисловий Дніпродзержинськ.

Обласний центр обороняли підрозділи Південного фронту, а саме Резервна армія у складі 30-ї, 255-ої, 275-ої стрілецьких дивізій, 28-ої кавалерійської, 8-ої та 12-ої танкової дивізій, 11-ої стрілецької бригади та курсанти Дніпропетровського артилерійського училища. Найзапекліші бої розгорнулися на західних та південно-західних підступах до міста. Про певну хаотичність прийняття управлінських рішень радянським командуванням непрямо свідчить доля курсантів Артилерійського училища, яке ще 23 серпня 1941 р. готувалося до евакуації в Томськ. Утім, активність Вермахту, а також директиви про неможливість залишення Дніпропетровська, призводять до того, що курсанти училища займають оборонні рубежі в районі залізничного розїзду Фабричний, де 24 серпня веде свій перший бій, який тривав 13 годин. Ранком наступного дня курсанти училища, а також інші підрозділи Червоної армії переходять залізничним мостом на лівий берег Дніпра. Не зважаючи на те, що майже протягом місяця тривали бої за лівобережну частину міста, саме від дня 25 серпня 1941 р. можна вести мову про встановлення нацистського окупаційного режиму, який протриває майже 26 місяців.

Окупація області ворожими військами передбачала створення тут органів влади і управління військового та цивільного характеру. Як відомо, в часи окупації Дніпропетровська область входила до рейхскомісаріату Україна с центром у місті Ровно (Рівне). Цей рейхскомісаріат (на чолі з Е. Кохом) був поділений на 6 генеральних округів, один із яких називався «Дніпропетровськ» і включав у себе 
всю Дніпропетровську та частину Запорізької області (інша її частина входила до округу «Таврія») [30, с. 138].

Відразу після окупації Дніпропетровськ і вся область входили до німецької тилової зони, а отже, підпадали під юрисдикцію військового управління. Військовим комендантом м. Дніпропетровська був призначений полковник фон Альберті. 3 відсуненням лінії фронту на схід, 15 листопада 1941 р., на території Дніпропетровської області було введено цивільне управління і встановлено адміністрацію рейхскомісаріату «Україна». Генеральний комісаріат «Дніпропетровськ» очолив генерал-комісар Публіг. Комісаром міста в Дніпропетровську був Клостерман [14, с. 81, 159]. Генеральний комісаріат та окружні адміністрації (гебітскомісаріати) складалися 3 таких відділів: господарського, заготівель і постачання, архі-вного, кадрового, житлового, харчування, культури, науки і мистецтва, медичного, фінансового, праці, сільськогосподарського та ін. Відомі і очільники деяких відділів. Так, господарські питання Дніпропетровська знаходилися у віданні Херрозе, а начальником сільськогосподарського відділу був Шайне [19, с. 171].

При групах німецьких армій діяли повноважні представники поліції безпеки і СД. За ними закріплювалися оперативні групи (Einsatzgruppe) (всього 4 - «A», «В», «C», «D») для «виконання особливих завдань, швидкого придушення опору в захоплених фронтових та тилових районах». На території України діяли айнзацгрупи «C» $\mathrm{i}$ «D». Їхнім головним завданням було «упокорення» населення шляхом викорінення можливого прояву незадоволення населення, а тим більше опору новому окупаційному режиму. Одним із напрямів їх діяльності мало стати знищення усіх небажаних у расовому відношенні осіб - чоловіків, жінок і дітей. Айнзацгрупи здійснювали страти людей відразу після окупації населених пунктів.

На окупованій території діяли і розвідувальні відділи абверу - військової розвідки та контррозвідки. Вони мали право втручатися у справи поліції, залучаючи їі до боротьби з радянськими диверсантами, розвід групами та партизанами. Охоронна поліція, яка підпорядкувалася міським і польовим комендатурам, контролювала в'язниці й концентраційні табори. Окрім виконання суто каральних функцій, вона допомагала айнзацко-мандирам здійснювати фільтрацію військовополонених, виявляти «політично небажані елементи», євреїв та інших «расово чужих осіб». На зміцнення окупаційного режиму спрямовувалася і діяльність польової жандармерії, на яку було покладено функції регулювання 206 
руху транспорту, контролю системи перепусток, обліку населення, розслідування злочинів за поданням комендантів місцевих комендатур, нагляду за місцевою поліцією тощо. Поліційні командири мали господарські ланки: для встановлення і контролю цін, закриття підприємств, вилучення товарів, накладення грошових штрафів та інших стягнень. Усі названі органи влади і управління мали необмежене право покарання населення за будь-яке порушення встановленого порядку.

Для упокорення місцевого населення, яке не хотіло дотримуватися пра-вил дії окупаційного режиму, німецьке командування застосовувало не тільки охоронні команди, але й польові дивізії. До складу охоронних команд та військових команд адміністративно-господарської служби додавалися допоміжні війська і поліційні формування $з$ місцевих жителів, тобто українська допоміжна поліція. Так, у Дніпропетровську українська допоміжна поліція займалася прийомом місцевих жителів віком від 17 до 35 років. Бажаючі стати поліцаями, як говорилося у відповідному оголошенні, повинні були звертатися із заявами до батальйону, що розташовувався за адресою: вул. Жуковського, 33 [16, с. 85].

Міську управу очолив росіянин за національністю, інжененер, випускник Харківського сільськогосподарського інституту П.Т. Соколов (Соколовський). Один з керівників націоналістичного підпілля у Дніпропетровську В. Регей про нього пише: «Я був переконаний, що він зайняв цю посаду за дорученням більшовицького підпілля і тому так ревно виявляє прихильність до німецької адміністрації» [31, с. 27]. Формування органів місцевого самоврядування у Дніпропетровську і області розпочалося відразу після їх захоплення німецько-фашистськими військами. Очевидно, що це не могло би відбутися тільки завдяки місцевим активістам без допомоги досвідчених осіб. Тим більше без організаційних заходів німецької влади, яка проте спочатку й не перешкоджала їх виник-ненню та діяльності. У зв'язку з цим звернемося до питання про роль похідних груп ОУН на Дніпропетровщині в організації суспільно-політичного і громадського життя.

Після початку німецько-радянської війни, коли з'явився шанс на відновлення самостійності України, радикальне крило ОУН, очолюване С. Бандерою, сформувало три похідні групи бійців загальною кількістю п’ять тисяч осіб для організації місцевої цивільної адміністрації на окупованій території з перспективою по завершенні війни перетворення iї в органи влади на місцях вже незалежної держави [24, с. 33]. 
Південна похідна група ОУН на чолі з Теодором Семчишиним (псевдонім - «Річка») на територію Дніпропетровської області вступила ще до іiі окупації нацистами. Один із членів цієї групи, референт зв’ язку Василь Регей (псевдонім - «Кіт»), у своїх спогадах «Від Сяну до Дніпра» пише: «Коли дісталися до Дніпропетровська, почули гарматні стріли і цокотіння скорострілів з лівого берега Дніпра. Недалеко вибухали бомби. Большевики були ще по той бік Дніпра, коли моя підгрупа зв'язку увійшла до міста. Отаборилися у передмісті в якійсь глибокій балці, де стояла якась італійська частина. Були обережними, малими групами перебиралися в центр міста на заздалегідь підготовлені помешкання.

Ніхто нас не зупиняв, коли ми навіть підводами заїхали в центр міста. Я зупинився в помешканні по вулиці Лібкнехта, 13 у художника Тараса Максименка. Його син Юрій ще зараз живий. Інші зупинилися на проспекті ім. Карла Маркса та його провулках, недалеко від Дніпра. Місто було бомбардуванням знищене. В невеличкій камениці розташувався штаб Похідної групи, а в дворі розташувалися вози з вантажем. Ми везли друкарські машинки, зброю, харчі, папір, літературу та інше майно Похідної групи, в тому числі й ліки, якими опікувалася моя сестра Амалія.

Частина населення покинула місто. Нам було важко розмістити людей у цих залишених помешканнях. Ми вибирали кімнати в партерах і внизу, щоб забезпечитися від обстрілів. В цьому першому помешканні відбулася святкова нарада штабу Південної похідної групи з нагоди закінчення походу. Це було 3 серпня 1941 р. Тоді Зенон Матла офіційно перебрав провід над Південним краєм (псевдо - Святослав Вовк)» [31, с. 25-26].

На початку вересня 1941 р. на нараді місцевої національно свідомої інтелігенції, ініційованій професором Дніпропетровського транспортного інституту Панасом Олійниченком та крайовим провідником ОУН-б Зеноном Матлою, було обрано склад обласної управи на чолі 3 П. Олійниченком. Його заступником став В. Регей, член ОУН-б.

Оскільки певний час після окупації німцями міста влада в ньому повністю належала військовому коменданту фон Альберті, то від імені української громади саме до нього звернулися ініціатори за дозволом створити українські обласні та районні органи самоврядування. Такий дозвіл без проблем було отримано. Очевидно, така «безпроблемність» була пов'язана $з$ проголошуваними тоді німецьким командуванням гаслами про «щасливе майбутнє» України як «однієї з найбільших держав у сім'ї європейських народів» (мабуть, 208 
військовий комендант був ознайомлений із змістом інструкції Верховного командування Вермахту від 11 вересня 1941 р., спрямованої на отримання лояльності з боку українського населення в початковий період війни). Отже, отримавши юридичний документ на право здійснення влади над частиною населення і з приблизно окресленою компетенцією, керівники обласної адміністрації, яка офіційно називалася Обласним Державним правлінням, активно розпочали організацію роботи. Про автономну політичну діяльність українців не могло бути й мови. Абсолютне політичне безправ'я повинно було, за планами німців, перетворити людей у рабів, витравити в них прагнення до боротьби за свободу і незалежність. Німецькі окупанти всіляко підкреслювали своє зневажливе ставлення до слов'ян. В окупованих районах вводилася комендантська година, обмежувалося пересування населення, можливість вільно змінити місце проживання.

Окупаційна адміністрація здійснювала насильницьке переселення місцевих жителів з метою створення поселень німецьких колоністів. До Дніпропетровська було відправлено 2000 німецьких фахівців, для них було виділено найкращу, горішню, частину міста, 3 якої виселили все місцеве населення. Так виник німецький квартал, що зайняв майже третину міста в нагірному районі (вул. Комсомольська, Широка, Шевченківська та інші), межі якого утворювали укріплене замкнене коло, вигідне для оборони. План виселення населення Дніпропетровська 3 нагірної частини міста і утворення укріпленого району німецькі власті здійснили повністю. У грудні 1942 р., незважаючи на морози, німецька поліція виселила 3 намічених кварталів мирне населення, крім фольксдойчів. Сім'ї, де були переважно люди похилого віку і діти, були вигнані на вулицю. Загалом передбачалося переселити 13000 чоловік. Практика сегрегації реалізовувалась й у громадському транспорті міста. Вулицями Дніпропетровська їздили трамваї, передні місця яких призначалися тільки для німців [9, с. 10].

За такого жорстокого окупаційного режиму міська управа намагалася створити відносно терпимі умови для городян. У Дніпропетровську діяли 65 крамниць і 8 базарів, на яких торгували промисловими товарами і деякими продуктами (хліб розподілявся по картках, що видавалися управою). Місто обслуговували (в 1943 р.) 8 лікарень на 1800 місць, 9 поліклінік. У місті функціонували храми різних християнських конфесій [20, с. 616].

Одним із проявів нацистського беззаконня було впровадження принципів колективної відповідальності для місцевого населення. За антифашистські дії окремих осіб карали цілі населені пункти, 
розстрілювали заручників, палили домівки, кидали до в'язниць мирних людей. Наказ командувача 6-ї армії Вермахту Рейхенау від 10 жовтня 1941 р. проголошував, що не лише проти партизанів, але й проти мирних жителів треба вживати жорстокі заходи, якщо вони могли завадити диверсіям або повідомити про них, та не зробили цього. Безпідставно арештовуючи жителів, окупанти страчували їх за «акти саботажу», до яких вони не мали жодного відношення. У «Попередженні» коменданта Дніпропетровська від 6 грудня 1941 р. говорилося: «...У разі повторення подібних фактів будуть вжиті суворіші заходи. Закликаємо населення допомагати у попередженні подібних випадків». Приводом до арешту заручників слугував будь-який акт саботажу, диверсії, замаху проти окупантів, будь-яке «порушення» розпоряджень окупаційної влади. Страти здійснювалися майже в кожному населеному пункті. Так, у відповідь на замах проти німецького офіцера 2 грудня 1941 р. було розстріляно 100 заручників із числа мешканців Дніпропетровська [36, с. 298].

Першими жертвами нацистського режиму стали єврейські мешканці Дніпропетровська. 13 жовтня 1941 р. чоловіки, жінки та діти різного віку були примусово доставлені до Універмагу «Люкс» (нині - ЦУМ). Тут нацисти проводил обшук, під час якого забирали собі всі цінності, що перебували при них, а також гарний одяг, після чого вишукували в колону по чотири людини, обставили озброєною охороною і погнали вул. Карла Лібкнехта в напрямку Транспортного інституту. Слід зазначити, що в числі загальної колони були жінки і дівчата, люди похилого віку, чоловіки і діти різного віку аж до немовляти. Місце страти знаходилось біля міста Дніпропетровськ на території лісорозсадника у яру шириною 20-50 м. та глибиною 1030 м. Хворих та старих євреїв члени першої та другої роти відвезли на місце страти на машинах. При цьому члени першої та другої рот оточили вулиці, якими євреї йшли до місця страти. На пункті збору, що знаходився на відстані 50-100 м від яру, євреї повинні були скинути у скриню свої цінні речі. Незважаючи на холод - спочатку йшов дощ, потім пішов сніг - деякі євреї для обшуку з метою виявлення цінних речей, зму-шені були спочатку роздягтись.

Доставлені для розстрілу євреї були настільки численні, що не всі могли бути розстріляні в один день. Тому розстріл 14 жовтня 1941 р. настанням темряви був припинений. Решта євреїв повинні були провести ніч на території яру під відкритим небом. При цьому ступні абсолютно незахищених від холоду євреїв - чоловіків, жінок і дітей - вночі буквально вмерзли в землю. Вранці міцні чоловіки 
повинні були їх витягувати. Ще живих людей члени 1-й і 2-й рот відправили в яр, де вони були розстріляні таким же способом, як в попередній день. Після того, як територія, на якій євреї повинні були провести ніч, була від них очищена, встановлено, що в землі замерзли маленькі діти, які під час згону в попередній день були кинуті на землю і втоптані в землю прибуваючими. Там також лежали мертвими в замерзлій багнюці і дорослі євреї. Вночі ще живі євреї зробили спробу до втечі; проте вони були застрелені вартовими (не встановлено, були це члени СД чи члени першої або другої рот).

Ще близько 1000 євреїв розстріляла в місті протягом жовтня айнзат-цкоманда 6. У Ereignismeldung UdSSR № 135 від 19 листопада 1941 року ми читаємо: «3 приблизно 100000 євреїв, що жили в Дніпропетровську, приблизно 70000 бігли перед вступом до міста німецьких військ. 3 решти 30 000, приблизно 10000 були розстріляні 13 жовтня 1941 року командою вищого фюрера СС і поліції. До дня звіту оперативна команда 6 розстріляла ще 1000 євреїв, причому не вдалося уникнути того, що з причин значної нестачі фахівців, єврейські ремісники, які залучаються для термінових робіт із ремонту та інших справ, поки були залишені в живих. Вживаються заходи для ліквідації близько 1500 хворих провінційної психлікарні» [1, с. 9].

Додаткову інформацію ми знаходимо в звіті фельдкомендатури 240 (відділ VII) від 19 жовтня 1941 року: «Сврейське питання, оскільки мова йде тільки про місто Дніпропетровськ, можна вважати вирішеним. До початку окупації ще було близько 35000 євреїв. Заходами СД було охоплено близько 15000 євреїв, близько 15000 євреїв втікли в зв'язку з цими заходами і ще є залишок 3 5000 євреїв. Вже розпочаті роботи зі створення гетто внаслідок цього значно ослабли. На жаль, фельдкомендатура не була повідомлена про блискавично проведених заходах СД, так що видане кілька днів тому розпорядження фельд-комендатури про накладення контрибуції (копія додається), приречене на поразку. Фельдкомендатура мала намір надати штраф в розпорядження міської адміністрації для оздоровлення міських фінансів» [21, с. 153-156].

Тим не менше планомірне винищення єврейського населення міста про-довжувалось й надалі. Відповідно до повідомлення від 25 лютого 1942 р. у період «3 10 січня до 6 лютого 1942 р. у Дніпропетровську за законами військового часу були розстріляні 17 професійних злочинців, 103 комуністичних функціонерів, 16 партизан і приблизно 350 євреїв. Крім цього були ліквідовані 400 пацієнтів психлікарні «Ггрень» і 350 пацієнтів психлікарні «Васильківка» [21, 
с. 158]. Масштабний нацистський терор таврувався й у повідомленнях радянської пропаганди. Вже 6 вересня 1941 р. радінформбюро повідомило: «Захопивши Дніпропетровськ, фашисти по-звірячому розправилися з жителями, які не встигли покинути місто. Озлоблені тим, що в місті не виявилося ніяких запасів продовольства і цінностей, фашистські мародери вривалися до будинків і вбивали жителів. Службовець комунального відділу міської ради О. К. Приходченко, якому вдалося втекти з міста, розповів, що в будинку № 17 по вулиці Чичеріна фашисти пограбували всі квартири, а жителів зарубали. На Великій базарній вулиці п'яні фашистські солдати затримали трьох жінок. Гітлерівці прив'язали їх до стовпів і вчинили дике насильство, після чого їх вбили. Робітник Дніпровського залізничного депо М. А. Кузьменко повідомляв, що біля кладовища фашисти розстріляли кулеметами більше ста чоловік, які вчинили опір окупантам, що грабували їх будинки» [16, с. 270].

Ще одним «місцем смерті» став протитанковий яр, який знаходився в 4-х кілометрах від міста і 300 м. від селища Верхнє (нині район вул. Енергетична і Янгеля). Тут за свідченнями очевидців відбувалося винищення громадян, з жовтня 1941 р. і до останніх днів свого перебування у Дніпропетровську майже щоденно машинами привозили людей і там розстрілювали. 3 машин виводили групу роздягнених чоловіків та жінок, розстрілювали, а потім виводили наступну групу людей, яких змушували засипати землею трупи першої групи, після чого знову вели їх до машини, роздягали і в тому самому порядку розстрілювали. На останок окупанти трупи розстріляних спалювали. В цьому районі німці за період тимчасової окупації знищили від 18 до 20 тисяч мирних жителів [1, с. 300]. Розстріли проводилися також і у дворі школи № 9 по вулиці Мостовій, де фашисти розстріляли близько 500 осіб [6, с. 86]. Загалом же протягом окупації у Дніпропетровську було вбито близько 60 тисяч мирних жителів [2, с. 189].

Ще однією категорією осіб, які стали об'єктом нацистського терору були радянські військовополонені. У довідці НКВС УРСР від 26 серпня 1942 р. зазначалося, що у 348-му таборі Дніпропетровська утримувалося 1800 радянських військовополонених. Більше половини з них загинули внаслідок голоду і хвороб (щоденно вмирало по 5-8 чоловік). Полонених червоноармійців і командирів роздягали, їхні однострої та взуття використовували «для потреб німецької армії». Окупанти залучали полонених до розчищення мінних полів, будівництва мостів, залізниць та інших небезпечних 
для життя робіт. Годували падаллю, трупами коней, худоби, часто ж лишали без води, тримали просто неба, під дощем і снігом. За найменший прояв непослуху розстрілювали на місці, глумились навіть над тілами загиблих. У районі нинішнього Південного машинобудівного заводу після визволення міста від фашистів знайдено поховання розстріляних військовополонених $[12$, с. 54]. Усього за час окупації на Дніпропетровщині їх вбито понад 37 тисяч [12, с. 133].

Наприкінці 1942 р. у Дніпропетровську з числа військовополонених генерал-лейтенант Корнєєв сформував український добровільний корпус «Вільне козацтво». Усього, як зазначав Я. Д. Ісаєвич, близько 15 тисяч військових, 2 козацькі дивізії, сформовані із мешканців Дніпропетровської області, служили в частинах Вермахту.

Засобом винищення українців була організація штучного голоду. Аби збільшити поставки продуктів до рейху, нацисти вирішили забирати з України все, що можна, незважаючи на потреби місцевого населення. У пошуках продуктів жителі міст направлялися в села, де вимінювали їх на одяг та інші товари. Німці не лише розганяли базари і конфісковували всі продукти, що продавалися на них, але й переслідували городян при пове-рненні з сіл. На околицях міст їх зустрічали спеціальні поліцейські пости, які забирали добуті продукти. Цим грабуванням надавалась видимість законності [2, с. 37]. Міська управа Дніпропетровська 8 листопада 1941 р. прийняла постанову, в якій говорилося: «Торгівлю і обмін сільськогосподарськими продуктами в Дніпропетровську з селами заборонити місцевому населенню як незаконні. Продукти, які будуть вимінюватися, реквізувати і передавати органам української допоміжної поліції...» [10, с. 54]. Хлібними картками забезпечувалися лише ті, хто працював на окупантів. Норми видачі хліба були такі: на працюючого 250-300 грамів на день, на утриманця - 100 г [2, с. 49]. Непрацюючі були приречені на голод, який у містах став звичайним явищем, і багато городян змушені були перебратися в села.

Складовою частиною злочинної діяльності окупаційного режиму була жорстока політика примусової праці в окупаційних зонах та вивезення населення на примусові роботи до рейху. У серпні 1941 р. наказом А. Розенберга в окупованих землях введено загальну трудову повинність для людей віком 18-45 років [11, с. 15]. У спеціальній пам'ятці для німців в Україні підкреслювалося: «німецький солдат звільнив Україну від більшовизму. Українці зобов'язані нам цим, i тому повинні працювати понад усі сили. Робота українців повинна протікати під суворим контролем німців. 3 українцями слід дотри- 
муватися принципу: суворо, але справедливо! Ніколи не забувай, що населення 25 років отруювалося ідеями комунізму. Те, що українець добре виконує роботи, ще не доводить, що він не є більшовиком».

На окупованій території області були створені біржі праці, без відома яких не можна було отримати робоче місце, ні звільнитися з неї, ані поміняти місце роботи [13, с. 20]. Робочий день офіційно становив 10-12 годин на добу, але керівникам підприємств надавалося право збільшувати його до 14-16 годин. Населення виганяли на примусові роботи: очищення вулиць від снігу, будування укріплень тощо. При цьому зарплатня і продовольчі пайки були мізерними. Оплата понаднормової, нічної роботи, роботи у вихідні не здійснювалася. Продовольчі пайки українців дозволяли лише напівголодне іс нування і забезпечували 30 50 \% необхідного продовольчого мінімуму [22, с. 294].

Фашисти для забезпечення себе робочою силою створили спеціальні «трудові табори», до яких надсилалися юнаки та дівчата, захоплені німцями та поліцією на вулицях, які не мали відмітки біржі праці в паспортах. У Дніпропетровському трудовому таборі перебувало декілька тисяч молоді. Табір розташовувався в 3 км від міста. Ув'язнені жили в дерев'яних бараках. Робочий день тривав 14 годин. Працювали ув'язнені на відновленні Амурського залізничного вузла, виконуючи важкі земляні роботи. Раз у три дні їм видавали 170 грамів просяного хліба. Тільки завдяки кормовим бурякам, які їли ув'язнені, вони врятувалися від голодної смерті [37, с. 103].Однією з реалій окупаційного режиму стало насильницьке вивезення українців до Німеччини. Це невільництво XX ст. мало таку мету: вивільнити в промисловості і сільському господарстві Німеччини ресурси для армії; ліквідувати дефіцит робочої сили в дедалі зростаю-чому військовому виробництві (планувалось вивезти на кожних двох німецьких робітників три «остарбайтери»); підірвати сили українського народу, максимально «прорідити» захоплені області; послабити опір в окупованих районах; на випадок відступу народне господарство і Червону армію позбавити людських ресурсів.

Організацію масового вивезення населення України було покладено на спеціальну структуру - «Імперське бюро з використання робочої сили» під керівництвом Ф. Заукеля. На місцях через біржі праці діяли так звані «уповноважені» (комісари), які визначали «контингент». Виконання цього завдання здійснювалось у взаємодії німецької цивільної і військової адміні-страцій, місцевих органів управління, каральних органів, охоронних дивізій і військового командування та підрозділів вермахту. При цьому рейхсфюрер СС 214 
Г. Гіммлер вимагав від своїх підлеглих застосування найжорстокіших заходів для досягнення мети: «Діяльність міністерства праці... повинна бути підтримана найбільшою мірою... Під час обшуку сіл, особливо в тих випадках, коли виникне необхідність спалити ціле село, місцеве населення повинно бути примусово передане в розпорядження уповноваженого» [37, с. 131].

Розпорядження штадткомісара Дніпропетровська Клостермана, опубліковане 14 вересня 1943 р. в «Днепропетровской газете» зазначало: «Не дивлячись на оголошення суворих покарань, багато осіб, визнаних придатними до відбуття трудової повинності 1926-1927 pp. для відправки їх транспортом до Німеччини, або зовсім не з'явилися для відправки, або втекли під час відправки. Оскільки погрози тюремного ув'язнення суттєво не вплинули, то я дав розпорядження, щоб в усіх сім'ях, члени яких будуть ухилятися від відправки, конфіскували все рухоме і нерухоме майно доки зобов'язані не підкоряться закону трудової повинності» [22, с. 294]. На початку липня 1942 р. за відмову їхати до Німеччини у Дніпропетровську нацисти арештували 150 робітників залізничних майстерень [37, с. 74].

Зауважимо, що перша широкомасштабна кампанія набору робочої сили з України розпочалася внаслідок виконання інструкції А. Розенберга від 6 березня 1942 р. про набір 627 тис. робочих і селян у найближчий термін [28, с. 74]. Повідомлення Радінформбюро про жахливі методи фашистів під час «набору» робочої сили до рейху не можна вважати пропагандистським перебільшенням. Так, німецький журналіст Й. Кауш, котрий влітку 1943 р. два тижні перебував на окупованій території України, у своєму донесенні писав: «Під час відходу поїздів з набраними робітниками відбувалися жахливі сцени. Цих робітників відправляли в Німеччину не одразу, а ще довго тримали у пересильних таборах на українській землі за колючим дротом. За цей час там збиралися цілі села і люди голосили й оплакували цих «бідних вигнанців». У тих місцевостях, де жителі втекли до набору, треба було спалювати села» [20, с. 412]. Усього 3 українських земель на фашистську каторгу було вивезено 2,4 млн. чоловік (що становило майже 80 \% депортованих до Німеччини 3 СРСР), у тому числі з Дніпропетровської області - 176303 особи, а безпосередньо з Дніпропетровська - 75 тис. [4, с. 95].

Ще одна сфера діяльності окупаційних органів управління колоніальна експлуатація економіки України шляхом проведення грабіжницької фінансової, податкової політики, сприяння військово-економічним органам, товариствам і компаніям. Так, у Дніпро- 
петровську було засновано Товариство постачання струму в гирлі Дніпра (з обмеженою відповідальністю) з основним капіталом в 20000 марок. Метою підприємства було виробництво та розподіл електричного струму і керування зв'язаними з підприємствами Дніпропетровської генеральної округи, особливо тими, що існували досі під загальною назвою «Постачання електричного струму в Південній Україні». Товариство мало виключне право керувати і використовувати існуючі в центральній окрузі електростанції та споруди для розподілу електричного струму. Крім того, для ведення різного роду торгівельних справ була створена з центром у Дніпропетровську фірма «Брати Льобцек» (Україна) із капіталом у 100 тис. марок. Існуюче вже в Рівному товариство 3 обмеженою відповідальністю Маннесмана для торгівлі рудами та залізом в Україні, заснувало філію в Дніпропетровську з основним капіталом у 100000 марок. 3 центром у Дніпропетровську була також заснована фірма «В. Бістерфельд» з обмеженою відповідальністю, з основним капіталом у 100000 марок. Це підприємство займалося продукуванням та продажем хімічних і фармацевтичних продуктів [28, с. 106].

Популярне твердження радянської пропаганди про організовану еваку-ацію заводів і фабрик глибоко в радянський тил, а також безуспішні спроби окупантів відновити роботу підприємств не зовсім узгоджуються з іншими свідченнями. Скажімо, у листівці Дніпропетровського підпільного міському партії від лютого 1942 р. із закликом до населення вести активну боротьбу проти загарбників, говорилося: «З наших заводів фашисти вивозять станки і мотори» [14, с. 138]. Яким же було ставлення населення до нових реалій життя та окупаційної влади? 3 німецької точки зору населення України наприкінці 1941 р. - першій половині 1942 р. можна було поділити на чотири групи: 1) ті, хто ненавидів більшовиків, прагнув повернення приватної власності і був готовий до співпраці з німцями; 2) пристосуванці, які вибирали сильнішого; 3) віддані радянському режимові люди, що готові були боротися з окупантами; 4) абсолютна більшість населення, яка підкорялася німцям, але вичікувала подальшого розвитку подій [7, с. 126]. Контррозвідка німецької групи армій «Південь» оцінювала кількість українського населення, яке в жовтні 1941 р. займало вичікувальну позицію, в 90-95 \%, а 5-10 \% (євреї, партійні працівники, що залишилися, та частина молоді) поставилися до німців вороже [18, с. 26].

Для визначення соціальних груп, які пішли на співпрацю з окупаційним режимом, і з'ясування причин цієї співпраці особливий інтерес становить документ під назвою «Рік ідіотської влади» 3 осо216 
бистих паперів партизана Ф. Д. Крицького, датований 21 вересня 1942 р. У роздумах Крицького представлений зразок «масової свідомості» радянських людей, які намагалися пояснити причини поразок Червоної Армії в 1941-1942 pр. Зокрема, в документі зазначалося: «Елементи, котрі були невдоволені радянською владою, пішли в обійми німецькому фашизму. Що це за люди? Перша категорія: це група фашистів-германофілів, яка відверто заявила орієнтир на Захід. Друга категорія: це група куркульства, репресованого в роки Радянської влади. Третя група: це група проміжних дурнів між куркульством і середняцтвом, між крупними і дрібними чиновниками... Головним чином, це сільське учительство, яке зараз посіло місця в основному старост і поліції. Четверта група: це люди, які не мають ані сили, ані волі, ані духу. Вони за будь-якої влади працюють мовчки, аби їх не чіпали... П'ята група, остання: це «комуністи», точніше носії партійних квитків, без комуністичної свідомості, кар'єристи, зрадники... елемент, що розклався...» [27, с. 34].

На нашу думку, до першої і п’ятої груп належали одиниці. Про другу та третю групи говорилося вище, а на особливу увагу заслуговує четверта, найбільш чисельна в будь-якому суспільстві група. Німці навіть у січні 1943 р. оцінювали цей прошарок суспільства в $60-70 \%[17$, с. 123,130$]$. У цілому мирне населення більше цікавилося економічними і побутовими, ніж політичними проблемами. Настрої людей значною мірою залежали від становища $з$ продовольством, від роботи, від чуток та політичних перспектив. Головною метою представників цього суспільного прошарку було прагнення пристосуватися до життя в нових умовах. Якщо інші соціальні групи ще на початку війни позначили своє позитивне або негативне ставлення до окупантів, то від перемоги в боротьбі за вплив на цю аполітичну, інертну «мовчазну більшість» багато в чому залежала ситуація в країні, міцність окупаційної влади.

Масові політичні репресії, трагедія Голодомору 1932-1933 рр., також багатьом принесли розчарування або й ненависть до радянської влади. Вони зачепили всі українські соціальні верстви: інтелігенцію, селян, робітників, військових, державних службовців. С. Кульчицький оцінює загальні втрати УРСР від Голодомору та репресій за 1933-1939 pp. у 4,2 млн. чоловік [25, с. 51], і це при тому, що населення України за переписом 1939 р. складало 30,9 млн. осіб. 3 огляду на ці дані прямі втрати складали ніяк не менше 13\%. Отже, велика кількість 3 тих, хто пережив політичні репресії та їхні близькі мали підстави негативно ставитися до радянської влади і потенційно могли вітати ії повалення. 
Інші соціальні групи, які могли вітати прихід німецьких військ переслідувані за релігійні переконання та націоналісти, були дуже нечисленними, особливо у Дніпропетровській області. Однак і вони впливали на загальні суспільні настрої. Так, християни всіх віросповідань, після жахливих сталінських переслідувань, теж із полегшенням зустріли німецькі війська. Генерал-комісар Дніпропетровська в квітні 1942 р. повідомляв, що «підтримкою державних установ зроблено благодатний вплив на віруючі верстви населення, які вбачали головне зло більшовизму в придушенні релігійної свободи». Про те, що частина священнослужителів і віруючих вітала прихід німців пише і Н. Волкових [3, с. 10].

За віковою ознакою настрої населення також мали суттєві відмінності. Молодь, вихована в комуністичному дусі, у великій мірі твердо стояла за радянську владу. У німецькому документі «Наслідки німецького воєнного управління в зоні армій «Південь» говориться, що радянська молодь «глибоко засвоїла основні положення більшовизму... Тому прорадянські вихована молодь після вступу німецьких військ являла собою постійну загрозу суспільному спокою, порядку та безпеці» [37, с. 109]. Серед старшого покоління противників радянської влади було значно більше. Оскільки ці люди пам'ятали дорадянські часи і вони не піддавалися з дитинства більшовицькій пропаганді, то й їхній світогляд, сформований на некомуністичних цінностях, суттєво відрізнявся від світогляду молоді. Гнітюче враження на настрої населення, а отже і на його ставлення до протиборчих сторін, мали поразки і відступ радянських військ. Це стало одним із чинників, який сприяв зміцненню «нового порядку», оскільки призводило до втрати віри в те, що радянська влада колись повернеться. Навіть серед багатьох комуністів проявлялися розгубленість і страх [33, с. 408].

Небажання частини українців захищати сталінський режим проявилося і в такому явищі, як дезертирство. У зв'язку з цим ще одну відносну лінію поділу між прихильниками і противниками радянської влади виділяє Ю. Ніколаєць. За його думкою, вона пролягала між тими, чиї родичі служили в Червоній Армії і тими, чиї близькі дезертирували з неї. В основному, перші бажали перемоги Червоній Армії, аби їхні родичі скоріше повернулися додому, а другі - негативно поставилися до влади [29, с. 17]. Після залишення Дніпропетровська і відступу його оборонців на лівобережжя Дніпра на деякий час наступило затишшя. В. Регей, член Південної похідної групи ОУН, зазначав: «Ніхто нас не зупиняв, коли ми навіть підводами заїхали в центр міста» [31, с. 25]. Він же свідчить про допомогу місцевих жителів, хоча вони й вважали іноді прибульців переодягненими німцями. 
Проте вичікувальні та лояльні настрої населення Дніпропетровська та області щодо окупантів протрималися недовго. Окупаційний режим дуже швидко відштовхнув від себе майже всіх потенційних союзників: селян через збереження колгоспів, робітників у містах - через голод і важкі умови життя, інтелігенцію - через нищення культури і духовне пригнічення, націоналістів - через репресії проти прихильників ідеї незалежної української держави. Якщо до сказаного додати, що члени багатьох родин у цей час перебували в лавах Червоної армії чи разом із підприємствами були евакуйовані в глибокий тил і працювали на перемогу над ворогом, то навіть нелогічно допускати їх лояльне ставлення до окупантів, а тим паче співробітництво. Тому можна вірити словам одного 3 німецьких урядовців, про тих українців, які «вітали нас визволителями, а сьогодні байдужі до нас і вже починають переходити до ворожого табору» [6, с. 93]. Це було сказано на початку 1942 p. За даними німецької контррозвідки групи армій «Південь» влітку 1943 р. 95 \% населення Дніпропетровщини було вороже налаштоване до німців [7, с. 392]. А вже в листопаді-грудні 1943 р. у плані роботи штабу партизанського руху (ШПР) 3-го Українського фронту, в смузі дій якого перебувала й частина Дніпропетровщини, зазначалося, що місцеве населення масово вступає в діючі або стихійно об'єднується в дрібні партизанські групи і загони [8, с. 149]. До цього ж часу відносить й оцінка ситуації у Дніпропетровську одним з учасників похідної групи ОУН: «Серед населення росте гнів та бажання помсти. Передовсім серед робітництва та нижчих сфер населення зміцніли революційні настрої без точно оформленої ідеї. «Бити німців» - і все... На запитання «Що нам робити?» - хтось коротко відповів: «Бити німців». Настрої пробільшовицькі ще дуже сильні. Багато вірить у скорий прихід більшовиків. «Хай буде гірше, але інше». Деякі з радістю цього ждуть» [26, с. 25]. Безумовно, що на зміну настроїв місцевих жителів вплинула і ситуація на фронтах, особливо Сталінградська битва. Це наочно ілюструє й донесення німецького командування від 25 серпня 1943 р. про настрої жителів Бердянська, Новомосковська та Дніпропетровська, в якому говориться, що населення постійно зважує шанси воюючих сторін на перемогу і намагається «своєчасно пристосуватися для забезпечення милості Червоної Армії». А проявляються ці настрої у посиленні саботажу німецьких заходів, протидії відправлянню молоді до Німеччини, у небажанні робітників та селян виходити на роботу тощо [14, с. 135]. 
Весь названий комплекс причин з початком 1942 р. різко і швидко змінює ставлення населення до окупаційного режиму. Зміна настроїв людей саме в цей час обумовлена кількома чинниками. По-перше, тоді почалося насильницьке вивезення українців на примусові роботи до Німеччини, що лютому 1942 р. було оприлюднено новий німецький аграрний лад, який не виправдав сподівань українських селян; по-третє, свавільний, расистський і терористичний характер окупаційного режиму за кілька місяців відкрив українському населенню справжнє обличчя нацизму; по-четверте, поразка вермахту під Москвою взимку 1941-1942 рр. справила великий психологічний вплив на населення окупованих областей, підбадьоривши прибічників радянської влади і змусивши іï противників бути обережнішими у виявленні своїх уподобань.

Таким чином, ставлення населення Дніпропетровщини до нацистського окупаційного режиму протягом всього періоду окупації не було однаковим. Воно пройшло певну еволюцію в залежності від політики, яку проводили нацисти, і залежало від соціальної і територіальної належності громадян, а також коливалося під впливом воєнних, політичних та економічних чинників.

\section{БІБЛІОГРАФІЧНІ ПОСИЛАННЯ}

1. Архів управління СБУ по Дніпропетровській області. Ф.1. - Оп. 1 Стр. 66. Дело с материалами о злодеяниих нацистов в г. Днепропетровске, Кривом Рогу, Никополе, Пятихатках (24 лиспопада 1943 р. - 12 листопада 1945p.) - 101 арк.

2. Борисов Г. А. Неизвестный Днепропетровск / Г. А. Борисов // Спадщина. Зб. статей. - Дніпропетровськ: Арт-Прес, 1999. - С. 189-198.

3. Волоковых Н. П. Общественное сознание граждан СССР на оккупированной территории Северо-Запада Российской Федерации в годы Великой Отечественной войны: автореф. дис. канд. ист. Наук / Н. П. Волоковых. Санкт-Петербург, 2002. - 18 с.

4. Грімстед П. К. Нищення українських музеїв, архівів, бібліотек у роки Другої світової війни / П. К. Грімстед, Г. Боряк // Пам'ятки України. - 1994. - № 3. - С. 93-98.

5. Грушевой К. С. Тогда, в сорок первом... / К. С. Грушевой. - М.: «Известия», 1976. $-271 \mathrm{c.}$

6. Державний архів Дніпропетровської області (Далі - ДАДО). - Ф. 19. Оп. 4. - Стр.52. - 186 арк.

7. ДАДО. - Ф. 2276. - Оп. 1. - Спр. 22. - 328 арк.

8. ДАДО. - Ф. 2276. - Оп. 1. - Спр. 44. - 406 арк.

9. ДАДО. - Ф. 2276. - Оп. 1. - Спр. 935. - 54 арк.

10. ДАДО. - Ф. 2311. - Оп. 1. - Спр. 104. - 106 арк.

11. ДАДО. - Ф. 2443. - Оп. 1. - Спр. 1. - 184 арк.

12. ДАДО. - Ф. 2443. - Оп. 1. - Спр. 7. - 146 арк.

13. ДАДО. - Ф. 2443. - Оп. 1. - Спр. 81. - 354 арк. 
14. Днепропетровская область в годы Великой Отечественной войны Советского Союза (1941-1945). Сб. док. и мат. - Д.: Днепропетровское кн. изд., 1962. - 362 с. 15. Днепропетровск глазами очевидцев: 1929-1942 / Сост. Г. Гуляев, Н. Д. Бусыгина. - Днепропетровск: Б.м., 2012. - 274 с.

16. Днепропетровску 200 лет. 1776-1976. Сб. док. и мат. - Київ: Наук. думка, 1976. -224 с.

17. Історія селянства Української РСР: у 2 т. - К.: Наукова думка, 1967. - Т. 2. - 486 с. 18. Загорулько М. М. Крах плана «Ольденбург»: (О срыве экономических планов фашист-ской Германии на оккупированной территории СССР) / М. М. Загорулько, А. Ф. Юденков. - М.: Экономика, 1974. - 383 с.

19. Коваль М. В. Україна в Другій світовій і Великій Вітчизняній війні (1939-1945) / М. В. Коваль. - Київ: Альтернативи, 1999. - 336 с.

20. Косик В. Україна під час Другої світової війни. 1938-1945 / В. Косик. Київ; Торонто; Париж, Нью-Йорк, 1992. - 729 с.

21. Круглов А. Холокост в Украине: Рейхкомиссариат «Украина», Губернаторство «Транснистрия»: монография / А. Круглов, А. Уманский, И. Щупак. - Днипро: Украинский инсти-тут изучения холокоста «Ткума»; ЧП «Лира ЛТД», 2016. - 356 с.

22. Клец В. К. Оккупационный режим и организация работы учебных заведений Днепропетровской области в период второй мировой войны / В. К. Клец // Наддніпрянський історико-краєзнавчий збірник. - Дніпропетровськ: ДДУ, 1998. - № 1. - С. 290-295.

23. Кучер В. Україна 1941-1944: трагедія народу за фасадом священної війни / В. Кучар, О. Потильчак. - Київ: Біла церква, 2011. - 368 с.

24. Кучер В. Спроба ОУН відродити незалежну українську державу / В. Кучер // 65-та річниця проголошення Акту відновлення Української Держави 30 червня 1941 року. - Київ: УВС, 2006. - 133 с.

25. Майоров М. Національний склад УРСР та Криму (за даними перепису населення СРСР 1939 року) / М. Майоров. - Режим доступу: http://likbez. org.ua/ua/census-data-for-the-ussr-in-1939.html

26. Матла 3. Південна похідна група / 3. Матла. - Мюнхен: Наша книгозбірня, 1952. $-32 \mathrm{c}$.

27. Мицик Л. М. Сучасна англо-американська історична література про партизанський рух на Україні / Л. М. Мицик // Укр. іст. журн. - 1990. - № 5. - С. 34-42. 28. Мєшков Д. Нові господарі: дніпропетровські архіви за німецької окупації / Д. Мєшков // Пам’ятки України. - 1994. - № 3-6. - С. 106-112.

29. Ніколаєць Ю. О. Морально-політичний стан населення і воїнів Червоної Армії в перший період Великої Вітчизняної війни на матеріалах України: автореф. дис... канд. іст. наук / Ю. О. Ніколаєць. - Київ, 1998. - 18 с. 30. Німецько-фашистський окупаційний режим на Україні. Зб. док. і матер. - Київ: Держви-дав УРСР, 1963. - 487 с.

31. Регей В. Від Сяну до Дніпра: Причинки до історії Південної похідної групи ОУН (фрагмент) ) / В. Регей; за ред. В. Панченка, упоряд. Ю. Щур, А. Середін // Дніпропетровська ОУН у боротьбі з німецькою окупацією (документи і матеріали). - Дніпропетровськ: Б. в., 2010. - 48 с.

32. Слободянюк М. А. Рух Опору на Дніпропетровщині в роки Великої Вітчізної війни (1941-1945) / М. А. Слободянюк, І. А. Шахрайчук. Дніпропетровськ: ДДУ, 1998. - 84 с. 
33. Субтельний О. Україна. Історія / О. Субтельний. - Київ: Либідь, 1991. - 720 с. 34. Касьянов О. В. Окупаційний режим на Дніпропетровщині в хронологічних довідках місцевих органів влади: Збірник документів / автори-упорядники О. В. Касьянов і Н. В. Киструська - Дніпропетровськ.: Герда, 2010. $380 \mathrm{c}$.

35. Центральний архів Міністерства оборони Російської Федерації. Ф. 228. - Оп. 701. - Спр. 4. - Арк. 316-317. - Режим доступу: https://pamyatnaroda.ru/documents/view/?

36. Шахрайчук I. А. Деякі аспекти діяльності легальних українських громадських об'єднань на Дніпропетровщині в період німецької окупації (19411944 рр.) / I. А. Шахрайчук, М. А. Слободянюк // Наддніпрянський історико-краєзнавчий збірник. - Дніпропетровськ: ДДУ. - № 1. - С. 295-301.

37. Шахрайчук I. А. У тенетах фашистської окупації / I. А. Шахрайчук // Історія Дніпропетровського національного університету. - Дніпропетровськ: ДНУ, 2003. - 232 с.

Надійшла до редкол.: 20. 12. 2017

УДК 94(477)«1941-1945»

DOI: $10.15421 / 231818$

\section{Із фронтів війни на посаду ректора}

Савчук В. С.

Дніпровський національний університет імені Олеся Гончара

Розглянуто історію призначення першого (після звільнення Дніпропетровська) ректора Дніпропетровського державного університету та період відновлення його діяльності після повернення з евакуації. Висвітлено життєвий шлях В. М. Полєжаєва, призначеного ректором Дніпропетровського держуніверситету наприкінці війни.

Ключові слова: Дніпропетровськ; війна; держуніверситет; ректор; В. М. Полєжаєв; життєвий шлях

Рассмотрены история назначения (после освобождения Днепропетровска) ректора Днепропетровского государственного университета и период возобновления его деятельности после возвращения из эвакуации. Освещен жизненный путь В. М. Полежаева, назначеного ректором Днепропетровского госуниверситета перед окончанием войны.

Ключевые слова: Днепропетровск; война; госуниверситет; ректор; В. М. Полежаев; жизненный путь

The history of the appointment (after the liberation of Dnepropetrovsk) of the rector of the Dnepropetrovsk State University and the period of his resumption after return from evacuation are considered. The life of V. M. Polezhaev, appointed by the rector of the Dnepropetrovsk State University before the end of the war, is studied. Data on the education he received before entering the Dnipropetrovsk Institute of Public Education are given. 